\title{
THE LIMITS OF COPYRIGHT: PROPERTY, PARODY, AND THE PUBLIC DOMAIN
}

\author{
MARLIN H. SMTTH
}

The origin and the primitive form of the language game is a reaction; only from this can more complicated forms develop.

Language-I want to say-is a refinement, "in the beginning was the deed." 1

\section{INTRODUCTION}

Parody has always enjoyed protection from claims of copyright infringement, under the doctrine of fair use, ${ }^{2}$ but a recent decision by the U.S. Court of Appeals for the Second Circuit, Rogers $v$. Koons, ${ }^{3}$ drastically narrows this statutory defense ${ }^{4}$ and threatens to eclipse the place of parody as fair use. It is not so much the outcome-a finding that the defendants infringed the plaintiff's copyright-that is troubling, but rather the court's contradictory application of the Copyright Act of $1976^{5}$ (the Copyright Act) to what would seem to be a clear case of fair use. Under the court's analysis, commercial parody is infringement per se at the expense of First Amendment freedoms of speech and the press.

Koons represents a misunderstanding of the purpose and scope of copyright as a form of property law. The purpose in

1. Ludwig Wittgenstein, Culture and Value 31 (G.H. Von Wright ed. \& Peter Winch trans., 1980) (quoting JOHANN W. VON GOETHE, FAUST, Pt. I (In the Study)).

2. Fair use is a "privilege in others than the owner of a copyright to use the copyrighted material in a reasonable manner without his consent." HORACE G. BALL, LAW OF COPYRIGHT AND LITERARY PROPERTY 260 (1944). This common law doctrine was first codified in the Copyright Act of 1976, 17 U.S.C. § 107 (1988 \& Supp. III 1991). See infra Part III.

3. 960 F.2d 301 (2d Cir.), cert. denied, 113 S. Ct. 365 (1992).

4. 17 U.S.C. $\S 107$.

5. Id. $\S \S 101-810$. 
authorizing temporary monopolies in creative works is to create a sufficient incentive for their production and eventual deposit into the public domain. ${ }^{6}$ Because the Copyright Act is a means of fulfilling the welfare aims of a constitutional provision, judicial analysis of fair use must be founded on a recognition of the primacy of the public domain. ${ }^{7}$

It is inevitable that the constitutional privileging of the public domain results in a restricted scheme of copyright, in light of the speech character of the property at issue. ${ }^{8}$ In permitting ownership of speech in its published form, copyright assigns virtually exclusive rights to that speech against non-owners, and herein lies the tension between copyright and First Amendment rights. Any regime that seeks to privilege some kinds of speech at the expense of others is deeply suspect, as the history of British censorship makes clear. ${ }^{9}$ Insofar as copyright constrains the published speech of non-owners, it is by necessity a uniquely limited form of property law. ${ }^{10}$ Were it otherwise, copyright owners could prohibit

6. Under the Constitution, Congress is authorized "[t]]o promote the Progress of Science and useful Arts, by securing for limited Times to Authors and Inventors the exclusive Right to their respective Writings and Discoveries." U.S. CONST. art. I, \& 8, cl. 8.

7. The public domain, which pre-dates the positive law of copyright, justifies the temporarily exclusive, private rights in intellectual property, since all copyrighted works will eventually enrich the public domain. See supra note 6 . However, the clear language of the Constitution notwithstanding, works under copyright are often perceived as being more "valuable" than materials in the public domain because the market pricing of the former is a familiar measure of worth. But to protect private copyright at the expense of the public domain could impoverish social discourse, see infra notes 202-06, creating a dysfunctional system of intellectual property rights:

To characterize the public domain as a quid pro quo for copyright or as the sphere of insignificant contributions .... is to neglect its central importance in promoting the enterprise of authorship. The public domain should be understood not as the realin of material that is undeserving of protection, but as a device that permits the rest of the system to work by leaving the raw material of authorship available for authors to use.

Jessica Litman, The Public Domain, 39 EMORY L.J. 965, 968 (1990).

8. Copyright governs the "Writings" of "Authors." U.S. CoNST. art. 1, \& 8, cl. 8. Under the Copyright Act, these "works of authorship" are broadly defined as "expressive works" or published forms of speech. 17 U.S.C. \& 102(a) (1988 \& Supp. III 1991).

9. See David Lange, The Speech and Press Clauses, 23 UCLA L. REv. 77, 94-95 \& nn.92-100 (1975) (outlining the history of the British Crown's control of speech and press through licensing and prosecutions for seditious libel).

10. These limitations distinguish copyright from other forms of property, in which exclusive rights of ownership and use might extend ad infinitum. For example, the Rule Against Perpetuities notwithstanding, cooperative heirs may sustain a system of wholly private property for a period of unlimited duration. Even the Takings Clause might be 
others from even speaking about copyrighted works in published form. Such "fair uses" preserve rights of speech and the press and are expressly reserved in the Copyright Act for the public domain. ${ }^{11}$ Copyright must not impinge on the public's First Amendment rights; it should guard against only that kind of economic harm posed by unauthorized copies that seek to replace the original. ${ }^{12}$ In assessing economic harm under the fair use test, courts should distinguish between a commentary and a functional equivalent to the original. ${ }^{13}$

The Koons court ignored these peculiarities of copyright law, granting broad protection to Rogers's copyright in the photograph at the expense of Koons's right to comment upon it in a parodic sculpture. ${ }^{14}$ In particular, the court's application of the fair use test is flawed in its presumption that the Copyright Act affords protection against any potential economic harm that a parody may pose to the original. ${ }^{15}$ The proper test of economic harm asks only whether the parody copies so much of the original that it serves as a replacement for that original. Only if the parody fails to identify itself as such, or incorporates so much of the original that it may be used as a substitute, should infringement be found.

This Note is premised on the theory that the temporary nature of copyright and the imperfect protection it affords are not only an incorporation of First Amendment concerns but also arise from basic resistance to wholly private ownership of intellectual property. This resistance derives from the substantive and social differences between the res of intellectual property and other forms of property ${ }^{16}$ and has constitutional, as well as practical

understood as a conversion of one form of private property (land) into another (money) rather than as the expiration of private property rights. See generally RESTATEMENT OF PROPERTY intro. note to Vol. IV 2130-31 (1944) (noting functions of the Rule Against Perpetuities).

11. 17 U.S.C. § 107.

12. See infra subsection $\operatorname{IV}(\mathrm{A})(4)$.

13. 3 MELVILLE B. NimMER \& DAVID NIMMER, NIMMER ON COPYRIGHT § 13.05[B] (1992) [hereinafter NIMMER ON COPYRIGHT] ("But if regardless of mediun, the defendant's work, although containing substantially similar material, performs a different function than that of the plaintiff's, the defense of fair use may be invoked.").

14. Rogers v. Koons, 960 F.2d 301, 312 (2d Cir.), cert. denied, 113 S. Ct. 365 (1992).

15. Id.

16. See Wendy J. Gordon, An Inquiry into the Merits of Copyright: The Challenges of Consistency, Consent and Encouragement Theory; 41 STAN. L. REV. 1343, 1378-79 (1989); David Lange, Recognizing the Public Domain, 44 LAW \& ConteMP. ProBS., 
and philosophical, dimensions. Koons is an example of the failure to analyze copyright in light of its limitations.

Part I of this Note outlines the facts and issues of Koons. Part II provides an overview of copyright as a limited form of property under both the Copyright Act and the common law, using Koons to illustrate the statute and the common law doctrines. Part III analyzes fair use as a major statutory limitation on copyright. Beginning with a rationale for fair use generally, this Part then discusses parody as a particular fair use and uses Koons as an example of the problems in recognizing parody as fair use. Part IV explains the four prongs of the statutory fair use test for parody and their application in Koons. In analyzing the reasoning of Koons, this Part shows that the court's presumptive rule against commercial copying is misplaced. It argues that the court's notion of economic protection under the Copyright Act is overly broad and compromises the First Amendment rights which the Act was meant to preserve. The proper test of economic harm is whether the copy serves to replace the original rather than merely to comment on it. Part $V$ argues that the limitations on copyright should be preserved in the case of parody because of First Amendment concerns rather than reliance on an economic rationale. These First Amendment concerns, incorporated in the Copyright Act, are consonant with the larger philosophical resistance to copyright as a form of private property. This Part argues that copyright is instead a system of gatekeeping, a means of maintaining a degree of public access to privately owned works even during their term of statutory protection. The Note concludes with a summary of the application of fair use in Koons. This Part argues that the overly broad interpretation of economic harm is an encroachment on fair use at the expense of First Amendment rights and the public domain. By clarifying the important limitations on the economic protection afforded copyright owners, the replacement test returns copyright to its proper role of preserving the public domain and balancing private property concerns against the public's First Amendment rights. 


\section{ROGERS V. KOONS}

In Rogers v. Koons, ${ }^{17}$ Art Rogers, a professional photographer, brought an action against sculptor Jeff Koons and the Sonnabend Gallery, which represented Koons, for copyright infringement and unfair competition in the creation and exhibition of a sculpture based on a reproduction of Rogers's copyrighted photograph. In 1980, Mr. and Mrs. Scanlon commissioned Rogers to make a photograph, subsequently entitled Puppies. The Scanlons purchased a print for $\$ 200$, and Rogers retained all rights to the image..$^{18}$ The photograph was exhibited at the San Francisco Museum of Modern Art in 1982..$^{19}$ In 1984, Rogers licensed the photograph to Museum Graphics, a commercial publisher, for reproduction and sale as a greeting card. ${ }^{20}$

In 1988, without Rogers's knowledge or permission, Koons used a greeting card of Puppies to create a painted sculpture entitled String of Puppies. Koons admittedly sent the front of the greeting card and an enlarged photocopy of Puppies to artisans at the Demetz Studio in Italy with instructions to create a three-dimensional, polychromed wooden sculpture. ${ }^{21}$ Koons intended that the sculpture look "just like the photo," albeit with embellishments such as round, clown-like noses on the blue puppies and daisies in the hair of the grinning man and woman in the photograph. ${ }^{22}$

The studio created three copies of String of Puppies from the artist proof, and the Sonnabend Gallery in New York City exhibited the sculpture as part of Koons's one-man "Banality Show," which opened on November 19, 1988. Koons intended that "the subject for the show would be Banality but the message would be a spiritual one. And while being uplifting, the ... work would be [a] critical commentary on conspicuous consumption, greed, and self indulgence."23 Koons sold the three copies of String of Puppies for a total of $\$ 367,000$, retaining the artist proof for himself, and shared the profits equally with Sonnabend. ${ }^{24}$ String of Pup-

17. 960 F.2d 301 (2d Cir.), cert. denied, 113 S. Ct. 365 (1992).

18. Id. at 304 .

19. Rogers v. Koons, 751 F. Supp. 474, 475 (S.D.N.Y. 1990), affd, 960 F.2d 301 (2d Cir.), cert. denied, 113 S. Ct. 365 (1992).

20. Koons, 960 F.2d at 304.

21. Id. at 305 . Demetz Studio ordinarily makes sculpture for religious use.

22. Id.

23. Koons, $751 \mathrm{~F}$. Supp. at $475-76$ (quoting Defendant's Main Brief).

24. Rogers v. Koons, 777 F. Supp. 1, 2 (S.D.N.Y. 1991), aff d, 960 F.2d 301 (2d 
pies was subsequently exhibited at the Los Angeles Museum of Contemporary Art, and Rogers learned of the sculpture when a photograph of it appeared in the Los Angeles Times on May 7, 1989..$^{25}$

Rogers, who then registered the photograph Puppies with the U.S. Copyright Office, ${ }^{26}$ brought an action against both Koons and Sonnabend Gallery to enjoin the exhibition of String of Puppies and to recover $\$ 367,000$ in compensatory damages and $\$ 2.8$ million in punitive damages. The district court granted the injunction $^{27}$ and summary judgment for Rogers on the issue of copyright infringement but reserved the determination of damages for trial. ${ }^{28}$ The U.S. Court of Appeals for the Second Circuit affirmed the summary judgment against Koons and Sonnabend in all respects, including the order that Koons turn over his artist proof of the sculpture to Rogers, pursuant to section 503(b) of the Copyright Act. ${ }^{29}$ Pursuant to section 504 of the Copyright Act, the court of appeals remanded for trial on the issue of damages. ${ }^{30}$ Noting that Rogers could claim either actual damages (as well as apportioned profits ${ }^{31}$ or elect statutory damages, ${ }^{32}$ the court rec-

Cir.), cert. denied, 113 S. Ct. 365 (1992).

.25. Koons, $960 \mathrm{~F} .2 \mathrm{~d}$ at 305.

26. Rogers obtained registration number VA 352/001, effective July 6,1989 , and the date of first publication was recorded as November 20, 1980. Koons, 751 F. Supp. at 476. See also infra note 32.

27. The district court originally ordered a permanent injunction against Koons and Sonnabend, pursuant to 17 U.S.C. § 502(a) (1988), and reserved for trial the issue of damages because of factual issues in dispute. Koons, $751 \mathrm{~F}$. Supp. at 480 . On reargument, the court found Sonnabend, along with Koons, to be "infringing sellers" for purposes of money damages. Koons, 777 F. Supp. at 2.

28. Koons, 751 F. Supp. at 481.

29. Although impoundment and disposition of infringing articles is a remedy available under 17 U.S.C. $\& 503$ (1988), the court did not order the impoundment or destruction of the three copies of String of Puppies sold to private collectors and did not address the question of whether these works might resurrect the issue of copyright infringement if they were to become available for resale.

30. Rogers v. Koons, No. 89-CV-6707-HAIGHT (S.D.N.Y. filed May 14, 1991).

31. Rogers v. Koons, 960 F.2d 301, 312 (2d Cir.), cert. denied, 113 S. Ct. 365 (1992). Under the Copyright Act, the copyright owner is entitled to recover not only actual damages suffered as a result of the infringement, but also "any profits of the infringer that are attributable to the infringement and are not taken into account in computing the actual damages." 17 U.S.C. \& 504(b) (1988). The copyright owner need only present proof of the infringer's gross revenue; the burden is on the infringer to prove any deductible expenses and "elements of profit attributable to factors other than the copyrighted work." Id. There is no provision for punitive damages under the Copyright Act.

32. Koons, 960 F.2d at 312. Judge Cardamone overlooked the fact that under the 
ommended "enhanced statutory damages," should Rogers elect the statutory option, because of Koons's "wilful and egregious behavior. ${ }^{, 33}$

\section{COPYRIGHT}

The analysis of parody as fair use begins with an understanding of the limitations of copyright imposed by the Copyright Act and the caselaw criteria for copyright eligibility developed in Feist Publications, Inc. v. Rural Telephone Service Co. ${ }^{34}$ The statutory limitations of subject matter, owner's rights, and duration of copyright distinguish the protections of copyright from the more expansive protection of tangible property. The judicial gloss on copyright eligibility-requiring expression, originality, and creativity-further restrict the scope of copyright. Koons illustrates these limitations. This Part also lays the foundation for an argument in favor of an expansive fair use doctrine in light of the speech character of parody and the primacy of the public domain..$^{35}$

\section{A. The Copyright Act of 1976}

The Copyright Act of 1976 is the latest in a long line of codifications of the common law of copyright. ${ }^{36}$ To state a claim

Copyright Act, statutory damages are available for registered works only, 17 U.S.C. $\S 412(2)$ (1988); NIMMER ON COPYRIGHT, supra note $13, \S 7.16[\mathrm{C}]$, and that Rogers had not registered Puppies until after discovering String of Puppies. See supra notes 26-27 and accompanying text. The statute is silent on the issue of retroactivity, but should Rogers be found ineligible for statutory damages, the amount for all infringements of any one work shall be "not less than $\$ 500$ or more than $\$ 20,000$ as the court considers just." 17 U.S.C. \& 504(c)(1). Two or more infringers unay be jointly and severally liable. Id;; see F.W. Woolworth Co. v. Contemporary Arts, Inc., 344 U.S. 228 (1952).

33. Koons, 960 F.2d at 313. Under the Copyright Act, if the copyright owner has proven willful infringement, the court, in its discretion, may increase the award of statutory damages to a maximum of $\$ 100,000.17$ U.S.C. $\$ 504(\mathrm{c})(2)$ (1988). A reduction of minimum damages from $\$ 500$ to $\$ 200$ is possible only where the infringer "was not aware and had no reason to believe that his or her acts constituted an infringement." Id.

34. 111 S. Ct. 1282 (1991).

35. See infra Part V.

36. Copyright protection existed at common law prior to the drafting of the Constitution. See 2 William Blackstone, COMMENTARIES ON tHE LAWS OF ENGLAND 407 (Univ. of Chicago ed. 1979). The original Copyright Act of 1790, passed during the second session of the First Congress, has been amended more than thirteen times, including major revisions in 1831, 1870, 1909, and 1976. L. Ray Patterson \& David Lange, Foreword: A Tribute to Robert W. Kastenmeier, 55 LAW \& CONTEMP. PROBS., Spring 1992, at 1. 
of infringement under the Act, the plaintiff must prove valid ownership of copyright ${ }^{37}$ and unauthorized copying by the defendant. $^{38}$ In Koons, the plaintiff's registration of copyright in the photograph Puppies was sufficient proof of ownership, ${ }^{39}$ and the defendant admitted that he had copied the greeting card. ${ }^{40}$

The subject matter of copyright is limited to "original works of authorship fixed in any tangible medium of expression . . . from which they can be perceived, reproduced, or otherwise communicated."41 "Works of authorship" include the literary, visual, dramatic, and performing arts as well as music, film, and architecture. ${ }^{42}$ Photography and sculpture fall within the category of "pictorial, graphic, and sculptural works," 43 as well as the narrower category of "visual arts," rights." ${ }^{45}$ Although the list of statutory subject matter is not

37. Although registration of copyright with the Copyright Office is not required for effective ownership, 17 U.S.C. $\S 410$ (1988), a certificate of registration is prima facie evidence of copyright ownership. Id. $\& 410$ (c).

38. Copying may be proved not only by direct evidence but also by circumstantial evidence of (1) access to the copyrighted work, and (2) "substantial similarity" between the works, as judged by the ordinary observer test. 3 NIMMER ON COPYRIGHT, supra note 13, \& 13.03[A]; see, e.g., Weissmann v. Freeman, 868 F.2d 1313, 1320 (2d Cir.), cert. denied, 493 U.S. 883 (1989).

The copying need not be deliberate; even unconscious copying may constitute infringement. See, e.g., ABKCO Music, Inc. v. Harrisongs Music, Ltd., 722 F.2d 988 (2d Cir. 1983) (finding composer George Harrison's unconscious copying of the song $\mathrm{He}^{\prime} \mathrm{s}$ So Fine in writing his own song, My Swcet Lord, to be an infringement).

39. Rogers v. Koons, 751 F. Supp. 474, 475 (S.D.N.Y. 1990), affd, 960 F.2d 301 (2d Cir.), cert. denied, 113 S. Ct. 365 (1992).

40. Koons, 960 F.2d at 305 .

41. 17 U.S.C. \& 102(a) (1988 \& Supp. III 1991).

42. Id. \& 102(a)(1)-(8).

43. Id. $\S 102(\mathrm{a})(5)$. These include "two-dimensional and three-dimensional works of fine, graphic, and applied art, photographs, prints and art reproductions, maps, globes, charts, diagrams, models, and technical drawings, including architectural plans." 17 U.S.C. $\S 101$ (1988).

44. A "work of visual art" is a painting, drawing, print, sculpture, or photograph either existing in a single copy or in a limited edition of no more than 200 copies that are signed and consecutively numbered by the author. Id.

45. Protection of the author's "moral rights" of attribution and integrity as against subsequent owners, 17 U.S.C. § 106A (Supp. III 1991), is available only to works of visual art. See infra note 219 and accompanying text. Thus, the following "pictorial works," as distinct from visual arts, fall outside the Copyright Act's moral rights protection:

poster, map, globe, chart, technical drawing, diagram, model, applied art, motion picture or other audiovisual work, book, magazine, newspaper, periodical, data base, electronic information service, electronic publication,... [or] any merchandising item or advertising, promotional, descriptive, covering, or packaging 
meant to be exclusive-in order to anticipate new media ${ }^{46}$ - the Act protects only "works of artistic craftsmanship," not strictly utilitarian works. ${ }^{47}$

Copyright protection is further restricted to a set of "exclusive" statutory rights ${ }^{48}$ that permit the owner to reproduce, display, and distribute copies of the protected work and to "prepare derivative works based upon the copyrighted work."49 Paradigmatic "derivative works" 50 include verbatim copies of the original $^{51}$ or reproductions of the original in other media, ${ }^{52}$ such

$$
\text { Id. }
$$

material or container.

46. 17 U.S.C. $\$ 101$ (1988). Under the Copyright Act, "works of authorship fixed in any tangible medium of expression, now known or later developed," may be eligible for copyright, and the recognized categories are not limited to those "include[d]" by the statute. Id. § 102(a). The currently recognized categories are the following: Literary works; nusical works; dramatic works; pantomimes and choreographic works; pictorial, graphic and sculptural works; motion pictures and other audiovisual works; sound recordings; and architecture. Id.

47. The category of "pictorial, graphic, and sculptural works" encoinpasses works of artistic craftsmanship insofar as their form but not their mechanical or utilitarian aspects are concerned; the design of a useful article [i.e., "an article having an imtrinsic utilitarian function that is not merely to portray the appearance of the article or to convey information," 17 U.S.C. \& 101] shall be considered a pictorial, graphic, or sculptural work only if, and only to the extent that, such design incorporates pictorial, graphic, or sculptural features that can be identified separately from, and are capable of existing independently of, the utilitarian aspects of the article.

Id. § 101; see, e.g., Mazer v. Stein, 347 U.S. 201 (1954) (sculpture used for lamp base independently eligible for copyright protection).

48. The "exclusivity" of $\S 106$ implies not only the conventional property right of the owner to exclude others from using the work, but also a statutory bar to expanding the rights of the owner. In contrast to the open-ended language of the fair use defense, see infra notes 115-22 and accompanying text, $\$ 106$ enumerates the rights of the owner, rather than suggesting examples of a broader scope of rights. See supra text accompanying note 49. Its language underscores the primacy of the public domain and the restricted nature of copyright as a form of property.

49. 17 U.S.C. $\S 106$ (1988).

50. The Copyright Act defines "derivative work" as

a work based upon one or more preexisting works, such as a translation, musical arrangement, dramatization, fictionalization, motion picture version, sound recording, art reproduction, abridgment, condensation, or any other form in which a work may be recast, transformed, or adapted. A work consisting of editorial revisions, annotations, elaborations, or other modifications which, as a whole, represent an original work of authorship, is a "derivative work."

Id. § 101 .

\section{Under the Copyright Act,}

"Copies" are material objects, other than phonorecords, in which a work is fixed by any method now known or later developed, and from which the work can be perceived, reproduced, or otherwise counmunicated, either directly or with the aid of a machine or dcvice. The term "copies" includes the material 
as the photograph of a sculpture, ${ }^{53}$ or, as in Koons, a sculpture made from a photograph. Insofar as the sculpture was found to be a reproduction of the photograph, Koons's creation, exhibition, and sale of String of Puppies would presumptively violate Rogers's rights, unless Koons could demonstrate fair use..$^{54}$

Copyright is also limited in duration. At some point, the copyright expires and the work is ceded to the public domain. For works created on or after January 1, 1978 (the effective date of the Copyright Act of 1976), copyright generally "subsists from [creation of the work] and ... endures for a term consisting of the [remaining] life of the author and fifty years after the author's death." 55 This "measuring life" of the author is adjusted for joint works, anonymous works, pseudonymous works, and works for hire. $^{56}$

\section{B. The Caselaw Criteria: Copyright Eligibility After Feist}

Judicial interpretations of which elements of a particular "work of authorship" are eligible for copyright add further restrictions to the statutory limits on copyright. ${ }^{57}$ First, copyright does not protect ideas but only the expression of ideas in a "tangible medium of ... embodiment." ${ }^{258}$ Furthermore, copyright protects Id.

object, other than a phonorecord, in which the work is first fixed.

52. These include the protected categories of tangible media of expression listed in $\S 102$ (a) of the Copyright Act. See supra note 42; see also Stewart v. Abend, 495 U.S. 207 (1990) (re-release of film version of short story after expiration of copyright in the film held to be an infringement of copyright in underlying short story).

53. See, e.g., Letter Edged in Black Press, Inc. v. Public Bldg. Comm'n of Chicago, 320 F. Supp. 1303 (N.D. Ill. 1970) (photographs of public sculpture by Picasso held to be derivative works for purposes of forfeiture and first publication under the common law).

54. See infra Part III.

55. 17 U.S.C. $\$ 302$ (a) (1988). For works created before this date, but not under copyright on January 1, 1978, copyright subsists from the effective date of the Act and endures for the remaining life of the author plus fifty years. Id. $\S 303$. For works already under copyright on January 1, 1978, the two twenty-eight year terms provided under the Copyright Act of 1909 are harmonized with the new Act such that the total period of protection runs for seventy-five years from the date the copyright was first secured. Id. $\S 304$ (a)-(b). See The Copyright Act of 1909, ch. 320, §§ 23-24, 35 Stat. 1075, 1080-81 (1909) (providing one 28 year term with a right of renewal and extension for an additional 28 years) (codified at 17 U.S.C. $\& 304(a)-(b)$ (1988)).

56. 17 U.S.C. \& 302(a)-(c) (1988).

57. See supra Section II(A).

58. Under the Copyright Act: 
only that part of the expression which originates with the author $^{59}$ and requires at least a modicum of creativity in that original expression. ${ }^{60}$

1. The Idea/Expression Dichotomy. The dichotomy between "idea" and "expression" is legally tenable if copyright is understood to protect only the tangible, property elements of creative expressions rather than the intellectual inspiration of producing them. ${ }^{61}$ In the landmark case of Feist Publications, Inc. v. Rural Telephone Service Co. ${ }^{62}$ the U.S. Supreme Court held that a telephone directory lacked the requisite creativity ${ }^{63}$ for copyright eligibility. The Court clearly distinguished ideas, which may not be copyrighted, from their expressions, which are eligible for copyright as "works of authorship":

[The] principle, known as the idea/expression or fact/expression dichotomy, applies to all works of authorship. As applied to a factual compilation, assuming the absence of original written expression, only the compiler's selection and arrangement may be protected; the raw facts may be copied at will. This result is neither unfair nor unfortunate. It is the means by which copyright advances the progress of science and art. ${ }^{64}$

As the Second Circuit recognized in Koons, "ideas, concepts, and the like found in the common domain are the inheritance of everyone. What is protected is the original or unique way that an author expresses those ideas, concepts, principles, or processes."65

A work is "fixed" in a tangible medium of expression when its embodiment in a copy or phonorecord, by or under the authority of the author, is sufficiently permanent or stable to permit it to be perceived, reproduced, or otherwise communicated for a period of more than transitory duration.

17 U.S.C. § 101 (1988).

59. Feist Publications, Inc. v. Rural Tel. Serv. Co., 111 S. Ct. 1282, 1287 (1992); 1 NIMMER ON COPYRIGHT, supra note $13, \S 1.08[C][1]$.

60. Feist, 111 S. Ct. at 1294.

61. "In no case does copyright protection for an original work of authorship extend to any idea, procedure, process, system, method of operation, concept, principle, or discovery, regardless of the form in which it is described, explained, illustrated, or embodied in such work." 17 U.S.C. \& 102(b) (1988). Note that this definition overlaps somewhat with the artistic/utilitarian distinction in the categories of subject matter eligible for copyright. See supra note 47.

62. 111 S. Ct. 1282 (1992).

63. See infra notes $59-60$ and accompanying text.

64. Feist, 111 S. Ct. at 1290 (citations omitted).

65. Rogers v. Koons, 960 F.2d 301, 308 (2d Cir.), cert. denied, 113 S. Ct. 365 (1992). 
In Puppies, it was not the idea of the proud couple and their German Shepherd puppies that was protectible but "Rogers's expression of this idea-as caught in the placement, in the particular light, and in the expressions of the subjects."

2. Originality and Creativity. Copyright is further limited by the fact that only that part of the work which originated with the author-that is, those elements of the work not copied from another or drawn from the public domain-is protectible. ${ }^{67}$ Traditionally, "originality" merely distinguished independent effort from direct copying. ${ }^{68}$ Since Feist, this term of art now requires at least a de minimis level of creativity as well. ${ }^{69}$ The impossibility of defining such terms does not detract from their usefulness in delineating copyright from the public domain. As one commentator has said, "[o]riginality is a conceit, but we like it."70

With regard to the originality of Puppies, the Koons court noted that "[e]lements of originality in a photograph may include posing the subjects, lighting, angle, selection of film and camera, evoking the desired expression, and alinost any other variant involved." "71 Although the court found evidence of selectivity in Rogers's production of the photograph, ${ }^{72}$ it did not point to the

66. Id.

67. Feist, $111 \mathrm{~S}$. Ct. at $1287 ; 1$ NIMMER ON COPYRIGHT, supra note $13, \S 1.08$ [C][1].

68. Alfred Bell \& Co. v. Catalda Fine Arts, Inc., 191 F.2d 99, 103 (2d Cir. 1951) (quoting Hoague-Sprague Corp. v. Frank C. Meyer Co., 31 F.2d 583, 586 (E.D.N.Y. 1929)) ("Originality in this context 'means little more than a prohibition of actual copying.'").

69. Feist, 111 S. Ct. at 1294 ("Originality requires only that the author make the selection or arrangement independently (i.e., without copying that selection or arrangement from another work), and that it display solne minimal level of creativity."). For a thorough explication of the originality and creativity requirements since Feist, see Howard B. Abrams, Originality and Creativity in Copyright Law, 55 LAW \& CONTEMP. ProBs., Spring 1992, at 3.

70. Litman, supra note 7, at 1019.

71. Rogers v. Koons, 960 F.2d 301, 307 (2d Cir.) (citing Burrow Giles Lithographic Co. v. Sarony, 111 U.S. 53, 60 (1884)), cert. denied, 113 S. Ct. 365 (1992); 1 NIMMER ON COPYRIGHT, supra note $13, \S 2.08[\mathrm{E}][1]$.

72. As the court noted,

Substantial creative effort went into both the composition and production of "Puppies" .... At the photo session, and later in his lab, Rogers drew on his years of artistic development. He selected the light, the location, the bench on which the Scanlons are seated and the arrangement of the small dogs. He also made creative judgments concerning technical matters with his camera and the use of natural light. He prepared a set of "contact sheets," containing 50 different images, from which one was selected. 
substantive elements of the work that might bear on its creativity. Instead, the court cursorily concluded that "Rogers's inventive efforts in posing the group for the photograph, taking the picture, and printing 'Puppies' suffices to meet the original work of art criteria." 73

\section{FAIR USE}

Although the "exclusive rights" afforded by the Copyright Act permit the copyright owner to effectively exclude some users-and thus to control some uses of the protected work-these rights are in no sense absolute. ${ }^{74}$ Some uses are reserved for the public domain under the fair use doctrine ${ }^{75}$ regardless of the author's personal contribution or, economic investment of the owner. ${ }^{76}$ As codified in the Copyright Act, this legislative policy choice reflects the unique legal status of copyright as property. Unlike the owners of tangible property, owners of intellectual property enjoy only a

Koons, 960 F.2d at 304.

73. Id. at 307 .

74. 17 U.S.C. \& 106 (1988); see supra notes $48-49$ and accompanying text. "The monopoly privileges that Congress may authorize are neither unlimited nor primarily designed to provide a special private benefit. Rather, the limited grant is a means by which an important public purpose may be achieved." Sony Corp. of Am. v. Universal City Studios, Inc., 464 U.S. 417, 429 (1984). As the Supreme Court explained in Sony,

This protection has never accorded the copyright owner complete control over all possible uses of his work. Rather, the Copyright Act grants the copyright holder "exclusive" rights to use and to authorize the use of his work in five qualified ways, including reproduction of the copyrighted work in copies. All reproductions of the work, however, are not within the exclusive domain of the copyright owner, some are in the public domain. Any individual may reproduce a copyrighted work for a "fair use"; the copyright owner does not possess the exclusive right to such use.

Id. at 432-33 (citations omitted).

75. See supra note 2; infra Part IV.

76. Nevertheless, Lockean rationales for private property ownership figure in the caselaw and the commentary of copyright. See, e.g., Harper \& Row, Publishers, Inc. v. Nation Enters., 471 U.S. 539, 546 (1985) (noting that copyright is "designed" to create a "fair return"); Gordon, supra note 16, at $1446 \mathrm{nn} .444-45$ (citing, inter alia, JOHN LOCKE, The Second Treatise of Government \& 27, in TwO TREATISES OF GOVERNMENT 283 (Peter Laslett ed., 1970)) ("For this Labour being the unquestionable Property of the Labourer, no Man but le can have a right to what that is once joyned to, at least where there is enough, and as good left in common for others.") (emphasis omitted).

The Supreme Court has, however, explicitly rejected the notion that the "sweat of the brow" doctrine alone can justify property ownership. Feist Publications, Inc. v. Rural Tel. Serv. Co., 111 S. Ct. 1282, 1296 (1992) (finding teleplone directory ineligible for protection where publisher "expended sufficient effort to make the white pages directory useful, but insufficient creativity to make it original"). See supra note 69 . 
temporary monopoly" over a much narrower field of "exclusive" rights. $^{78}$ As the Supreme Court said in Sony Corporation of America v. Universal City Studios, Inc. ${ }^{79}$ in which it found home videotape recording of copyrighted films to be a fair use,

The limited scope of the copyright holder's statutory monopoly, like the limited copyright duration required by the Constitution, reflects a balance of competing claims upon the public interest: Creative work is to be encouraged and rewarded, but private motivation must ultimately serve the cause of promoting broad public availability of literature, music, and the other arts. The immediate effect of our copyright law is to secure a fair return for an "author's" creative labor. But the ultimate aim is, by this incentive, to stimulate artistic creativity for the general public good. "The sole interest of the United States and the primary object in conferring the monopoly," this Court has said, "lie in the general benefits derived by the public from the labors of authors." 80

The traditional definition of fair use is "a privilege in others than the owner of a copyright to use the copyrighted material in a reasonable manner without his consent." 81 As long as the character of the copying is reasonable and the purpose legitimate, nonowners may use protected works without the owner's consent or license. Fair use is an "equitable rule of reason" 82 which "permits courts to avoid rigid application of the copyright statute when, on occasion, it would stifle the very creativity which that law is designed to foster." ${ }^{183}$ This rule implies that the law is designed to. encourage not only the creativity of the original authors but cre-

77. See supra notes $55-56$ and accompanying text.

78. See supra notes $48-49$ and accompanying text.

79. 464 U.S. 417 (1984).

80. Id. at 431-32 (quoting Twentieth Century Music Corp. v. Aiken, 422 U.S. 151, 156 (1975) (quoting Fox Film Corp. v. Doyal, 286 U.S. 123, 127 (1932))).

81. BALL, supra note 2 , at 260 . That fair use has also been deemed a "right" points to a persistent ambivalence towards copyright and fair use. In any case, the definition provides little guidance in determining what constitutes fair use in a particular case. Insofar as the right/privilege distinction obtains, this thesis proceeds from the notion that fair use is founded upon the First Amendment right of speech and publication. See supra notes 8-10 and accompanying text.

82. Sony, 464 U.S at 448 n.31 (quoting H.R. REP. No. 94-1476, 94th Cong., 2d Sess. 66 (1976), reprinted in 1976 U.S.C.C.A.N. 5659, 5680 ("[S]ince the doctrine is an equitable rule of reason, no generally applicable definition is possible, and each case raising the question must be decided on its own facts ....")).

83. Stewart v. Abend, 495 U.S. 207, 236 (1990). 
ativity among all users. In allowing others the limited copying or use of copyrighted works, fair use strikes a balance between the "exclusive" rights of owners and the public right of free speech. As the Second Circuit itself has said,

Whatever aesthetic appeal [a parody] ... may have results from the creativity that the copyright law is designed to promote. It is decidedly in the interests of creativity, not piracy, to permit authors to take well-known phrases and fragments from copyrighted works and add their own contributions of commentary or humor. After all, any work of sufficient notoriety to be the object of parody has already secured for its proprietor considerable financial benefit. According that proprietor further protection against parody does little to promote creativity, but it places a substantial inhibition upon the creativity of authors adept at using parody to entertain, inform, or stir public consciousness. ${ }^{84}$

\section{A. Parody as Fair Use}

Parody, as opposed to other satirical forms, ${ }^{85}$ is a comment made in direct response to the original. Parody must do more than generate humor; it

must also make some critical comment or statement about the original work which refiects the original perspective of the parodist-thereby giving the parody social value beyond its entertaininent function. Otherwise, any comic use of an existing work would be protected, removing the "fair" aspect of the "fair use"

84. Warner Bros. v. American Broadcasting Cos., 720 F.2d 231, 242-43 (2d Cir. 1983) (footnote omitted).

85. Parody is a "particular kind of satire," and "satire is a potent form of social commentary which attempts to expose the foibles and follies of society in direct, biting, critical, and often harsh language-tempered by humor." Harriette K. Dorsen, Satiric Appropriation and the Law of Libel, Trademark, and Copyright: Remedies Without Wrongs, 65 B.U. L. REv. 923, 924 \& n.5 (1985).

Although parody and satire each involve copying, they are distinct in their targets. In parody, the target of criticism is primarily another creative work and, necessarily, its formal or aesthetic properties. In satire, the target of criticism is primarily the subject matter of the original, e.g., an individual or institution which is ridiculed or derided, "usually with an intent to stimulate change ... . for the purpose of exposing and discred' iting vice or folly." Metro-Goldwyn-Mayer v. Showcase Atlanta Co-op. Prod., 479 F. Supp. 351, 357 (N.D. Ga. 1979) (quoting Dallas Cowboys Cheerleaders v. Pussycat Cinema, 467 F. Supp. 366, 376 (S.D.N.Y.), affd, 604 F.2d 200 (2d Cir. 1979)). 
doctrine and negating the underlying purpose of copyright law of protecting original works froin unfair exploitation by others. ${ }^{86}$

It is the critical force of parody, rather than a "merely . . . comic effect," ${ }^{87}$ which qualifies it as fair use if all of the statutory factors are met. Specifically, it is parody's criticism of the expression of the original that makes parody eligible for protection as fair use.

The distinction between humor and criticism-between satire and parody-is crucial to understanding the scope of fair use protection for parody. Like other paradigmatic fair uses-criticism, comment, news reporting, teaching, scholarship, and research $^{88}$-parody involves social discourse, that is, not just expression but the exchange of speech. The existence of the original-the fact that it has "spoken"--becomes the object of the parody and thus part of its content. ${ }^{89} \mathrm{~A}$ prohibition of parody in the name of copyright is thus tantamount to a content-based restriction on speech. Courts must analyze such restrictions with a heightened scrutiny not present in the Koons decision..$^{90}$

In Koons, the court held that "even given that 'String of Puppies' is a satirical critique of our materialistic society," sculpture did not constitute a fair use parody of the original. ${ }^{92}$ Although the court properly reasoned that the requirement that parody comment on a particular work ${ }^{93}$ is a necessary limitation on fair use copying, it used "parody" and "satire" inter-

86. Metro-Goldwyn-Mayer, 479 F. Supp. at 357.

87. New Line Cinema Corp. v. Bartlesman Music Corp., 693 F. Supp. 1517, 1525 (S.D.N.Y. 1988).

88. 17 U.S.C. \& 107 (1988 \& Supp. III 1991).

89. "That is, the first work's prior existence is not inerely a convenience that makes it possible for the later comer to save herself time and effort; rather, the prior existence of the reproduced work is an essential part of the message that the use seeks to convey." Wendy J. Gordon, Reality as Artifact: From Feist to Fair Use, 55 LAW \& CoNTEMP. PROBS., Spring 1992, at 93, 97 (footnote ounitted).

90. See, e.g., Perry Educ. Ass'n v. Perry Local Educators Ass'n, 460 U.S. 45 (1983) (noting that content based restrictions on speech must be necessary to serve a compelling interest and narrowly drawn to acheive that end).

91. Rogers v. Koons, 960 F.2d 301, 310 (2d Cir.), cert. denied, 113 S. Ct. 365 (1992).

92. Id.

93. See supra note 86 and accompanying text.

94. As the court noted,

It is the rule in this Circuit that though the satire need not be only of the copied work and may, as appellants urge of "String of Puppies," also be a parody of modern society, the copied work must be, at least in part, an object 
changeably ${ }^{95}$ The mistake was not harmless; the court's misinterpretation of the distinction led it to discount Koons's arguments about his larger satirical purpose ${ }^{96}$ as insufficient evidence of his intent to parody the Rogers photograph ${ }^{97}$ and to ignore the formal and contextual differences ${ }^{98}$ between the works which amply support Koons's claim that String of Puppies is a parody of Puppies. Without considering the relationship among the sculpture, the photograph, and the exhibition, the court collapsed why Koons found inspiration in the greeting card-that is, its perceived banality as a commercial work of art, which could be parodied-with how Koons used the parody-that is, to satirize a more pervasive cultural banality. ${ }^{99}$

Because the copying involved in parody is akin to quoting the original rather than misappropriating it, the audience must be aware of the original that the copy parodies. As the court explained in Koons,

of the parody, otherwise there would be no need to conjure up the original work.

We think this is a necessary rule, as were it otherwise there would be no real limitation on the copier's use of another's copyrighted work to make a statement on some aspect of society at large. If an infringement of copyrightable expression could be justificd as fair use solely on the basis of the infringer's claim to a higher or different artistic use-without insuring public awareness of the original work-there would be no practicable boundary to the fair use defense.

Koons, 960 F.2d at 310 (citations omitted).

95. The court found that Koons's sculpture "is a satire or parody of society at large." Id, at 309. "[T] hough the satire need not be only of the copied work, ... [the sculpture may] also be a parody of modern society ...." Id. at 310. The court, however, misused the terms: As parody is a comment upon a particular work, one cannot "parody" something like "society at large" or "modern society" but may perhaps satirize that social content of the original. See supra note 86 and accompanying text.

96. Koons styles himself to be in the traditions of Cubism, Dadaism (particularly the "readymades" of Marcel Duchamp), and Pop Art, which often parodied other works for the purpose of satirizing the rampant consumerism and materialism of modern society. Koons, 960 F.2d at 304, 309.

97. Id. at 310.

98. See infra notes $110-11$ and accompanying text.

99. As the court acknowledges,

Koons saw certain criteria in the notecard that he thought made it a workable source. He believed it to be typical, coinmonplace and familiar. The notecard was also similar to other images of people holding animals that Koons had collected. Thus, he [also] viewed the picture as part of the mass culture-"resting in the collective sub-consciousness of people regardless of whether the card had actually ever been seen by such people."

Koons, 960 F.2d at 305 (citation omitted). 
By requiring that the copied work be an object of the parody, we merely insist that the audience be aware that underlying the parody there is an original and separate expression, attributable to a different artist. This awareness may come from the fact that the copied work is publicly known or because its existence is in some manner acknowledged by the parodist in connection with the parody. ${ }^{100}$

However, the degree to which Puppies is "publicly known" is a question of fact, and the analysis in Koons is inconclusive. The court seemed to confuse public recognition of the work with the notoriety of its author. Although it found Puppies to be widely published, if not ubiquitous, ${ }^{101}$ the court emphasized instead the "professional backgrounds"102 and reputations of the artists. Although Rogers was an established professional, he was significantly less well-known than Koons, ${ }^{103}$ whom the court described as a "significant player[] in the art business,"104 with an international reputation and six-figure sales prices. ${ }^{105}$

The conflation of artist and image is commonplace ${ }^{106}$ and

100. Id. at 310.

101. After Rogers sold an undetermined number of prints in 1980, Puppies became part of his professional catalogue and was "used and exhibited a number of times" over the following years. Id. at 304. These uses included the sale of another signed print to a private collector, the reproduction of Puppies in an anthology (Dog Days), and the licensing of the greeting card to Museun Graphics, which has primted and distributed an estimated 10,000 copies of Puppies since 1984. Id. Koons himself bought one of the cards in a "very commercial, tourist-like card shop" in 1987. Id. at 305.

102. Id. at 303.

103. Id. Rogers resides in Point Reyes, California, far from the high-profile New York art market, and has taught photography at the San Francisco Museum of Modern Art. Id. at 303-04. In contrast to Koons's success, Rogers's work is in only three permanent collections: The San Francisco Museum of Art, the Center for Creative Photography at the University of Arizona, and Joseph E. Seagrams and Sons in New York City. Although his work has been exhibited in California, Maine, Florida, and New York and mentioned in various photography publications, there is no evidence that Rogers is particularly well-known. See $i d$.

104. Id. at 303.

105. The court described Koons as a New York artist with an extensive portfolio whose "works sell at very substantial prices, over $\$ 100,000$." Id. at 304. As evidence of Koons's international reputation, the court cited three galleries which showcased his work (Sonnabend in New York, Donald Young in Chicago, and Max Hetzler in Cologne, Germany) and his numerous exhibitions in 1980s. Id.

106. As David Lange explained:

We value authorship, or so we say insistently in the main theories of the field. And yet it appears, again and again, that we merely value some authors, and then at the expense of others. Eventually, it would seem, we must ask what it 
explains why parody is obvious if the original artist is more famous than the person parodying his work. ${ }^{107}$ Nevertheless, the test of recognition concerns the work-the "separate and original expression"-and requires only that it be attributable to a different artist, not necessarily one the audience can identify by name. Were it otherwise, the Koons court would imply that lesser-known or anonymous artists are exempt from fair use parody.

It is incumbent upon courts to engage in a close reading or formalist analysis of the works in question in order to gauge the degree of substantial similarity between them. ${ }^{108}$ While parody must be substantially similar to the original in order to make its critical point, it is the play of difference between the original and its mocking copy which gives the copy the status of parody. The Koons court, however, gave only brief consideration to the manifest differences between the sculpture and the photograph and failed to consider the works in their respective contexts of production and consumption. ${ }^{109}$

Puppies is a realistic portrait of a proud couple and their pets. String of Puppies, in contrast, is a garishly painted sculpture featuring clown-nosed, blue dogs and an insipid, smiling couple with flowers in their hair. ${ }^{110}$ Furthermore, the parodic elements of the sculpture are impossible to ignore given the context of the work-a public exhibition at the Sonnabend Gallery entitled the "Banality Show."111 It is significant that neither the district court nor the circuit court ever saw the actual sculpture and relied only

is, exactly, that we prize in authors.

David Lange, At Play in the Fields of the Word: Copyright and the Construction of Authorship in the Post-Literate Millennium, 55 LAW \& CONTEMP. PROBS., Spring 1992, at 139, 139-43.

107. Consider, for example, Duchamp's painting of da Vinci's Mona Lisa with a moustache, L.H.O.O.Q.

108. Substantial similarity is "determined by the ordmary observer test," which asks "whether an average lay observer would recognize the alleged copy as having been appropriated froin the copyrighted work," Koons, 960 F.2d at 307 (quoting Ideal Toy Corp. v. Fab-Lu Ltd., 360 F.2d 1021, 1022 (2d Cir. 1966)), or, alternatively, whether "the ordinary observer, unless he set out to detect the disparities, would be disposed to overlook them, and regard their aesthetic appeal as the same." Id. (quoting Peter Pan Fabrics, Inc. v. Martin Weiner Corp., 274 F.2d 487, 489 (2d Cir. 1960)).

109. Id. at 308 .

110. One viewer described the sculpted couple as "nightmarishly kitsch creatures with an evil twinkle in their eyes." Martin Gayford, The Arts: Voyage into Outer Taste, DAILY TELEGRAPH, Jan. 9, 1992, at 15.

111. Koons, 960 F.2d at 305 . 
a black-and-white photograph of it with the same dimensions as those of the greeting-card copy of Puppies. Perhaps this explains the court's emphasis on the similarities of the works rather than the differences between them that support a finding of parody.

\section{Koons as PAROdY UNDER THE FAIR USE TEST}

From the foregoing analysis of String of Puppies as parody, we turn to the court's application of each of the statutory fair use factors. The four pronged test of fair use, codified in section 107 of the Copyright Act, considers the purpose and character of the unauthorized use, the nature of the copyrighted work, the amount and substantiality of the copying, and its economic effect on the original. In Koons, the court misinterpreted dicta in Sony Corporation of America v. Universal City Studios, Inc. ${ }^{112}$ as creating a per se rule against unauthorized copying for commercial purposes. The court's indiscriminate application of the "economic effect" prong of the test impermissibly extends copyright protection to any economic harm resulting from the copy, in contravention to the purpose of the Copyright Act.

\section{A. The Fair Use Test for Parody}

For parody or any other unauthorized copy seeking protection as fair use, the statutory test requires a case-by-case analysis ${ }^{113}$ of statutory factors including:

(1) [T] he purpose and character of the use, including whether such use is of a commercial nature or is for nonprofit educational purposes;

(2) the nature of the copyrighted work;

(3) the amount and substantiality of the portion used in relation

to the copyrighted work as a whole; and

112. 464 U.S. 417 (1984).

113. "Beyond a very broad statutory explanation of what fair use is and some of the criteria applicable to it, the courts must be free to adapt the doctrine to particular situations on a case-by-case basis." H.R. REP. No. 1476, 94th Cong., 2d Sess., pt. 5, at 65-66 n.10 (1976), reprinted in 1976 U.S.C.C.A.N. 5659, 5680 n.73; see New Line Cinema Corp. v. Bertlesman Music Group, 693 F. Supp. 1517, 1525 (S.D.N.Y. 1988) (quoting Fisher v. Dees, 794 F.2d 432, 435 (9th Cir. 1986)) ("An assertion of the parody defense 'must be considered individually, in light of the statutory factors, reason, experience, and, of course, the general principles developed in past cases.' "); see also 3 NIMMER ON COPYRIGHT, supra note 13 , \& 13.05[A]. 
(4) the effect of the use upon the potential market for or value of the copyrighted work. ${ }^{114}$

The statutory list is not exclusive, ${ }^{115}$ and although no one element is dispositive, ${ }^{116}$ the effect on market value is given special weight. ${ }^{117}$ These factors constitute the basis for distinguishing fair use from infringement. ${ }^{118}$

The generality of the factors and the self-referential defimition of fair use ${ }^{119}$ contribute to an intentionally flexible test. ${ }^{120}$ The broad wording anticipates the development of new means of copying and accommodates the legislative decision to protect from infringement claims a panoply of categories that typically satisfy the test for fair use: ${ }^{121}$ criticism and comment, including parody; news reporting; teaching; scholarship; and research. ${ }^{122}$

1. Purpose and Character of the Use. The first prong of the statutory test considers the purpose for copying a protected work and the manner of doing so. Because parody is intended to closely

114. 17 U.S.C. \& 107 (1988 \& Supp. III 1991).

115. The Copyright Act states that '[t]he terms 'including' and 'such as' [in the statute] are illustrative and not limitative." 17 U.S.C. \& 101 (1988); see Harper \& Row, Publishers, Inc. v. Nation Enters., 471 U.S. 539, 560 (1985) ("The factors enumerated in the section are not meant to be exclusive ....").

116. See supra note 113.

117. Increasingly, effect on market value is treated as the "most important, and indeed, central fair use factor." Stewart v. Abend, 495 U.S. 207, 238 (1990) (quoting 3 NIMMER ON COPYRIGHT, supra note 13, \& 13.05[A]).

118. Section 107 is a mandatory test of fair use. Not only does the plain language of $\S 107$ require a consideration of these four factors, -17 U.S.C. $\S 107$ (1988) ("[T] he factors to be considered shall imclude .....") (emphasis added), but the Supreine Court has explicitly affirmed these requirements. See Sony Corp. of Am. v. Universal City Studios, Inc., 464 U.S. 417, 448-55 (1984).

119. See supra note 2.

120. Congress intended the Copyright Act of 1976 to "restate the present judicial doctrine of fair use, not to change, narrow, or enlarge it in any way." H.R. REP. No. 1476, 94th Cong., 2d Sess., pt. 5, at 66 (1976), reprinted in 1976 U.S.C.C.A.N. 5659, 5680; see Triangle Publications, Inc. v. Knight-Ridder Newspapers, Inc., 626 F.2d 1171, 1174 (5th Cir. 1980) ("Congress made clear that it in no way intended to depart froun Courtcreated principles or to short-circuit further judicial developinent . . . .").

121. "The statement of the fair use doctrine in $\S 107$ offers some guidance to users in determining when the primciples of the doctrine apply. However, the endless variety of situations and combinations of circumstances that can rise in particular cases precludes the formulation of exact rules in the statute." H.R. REP. No. 1476, 94th Cong., 2d Sess., pt. S, at 66 (1976), reprinted in 1976 U.S.C.C.A.N. 5659, 5680.

122. 17 U.S.C. $\S 107$. 
imitate or mimic the language or style of the original "for comic effect or ridicule," $" 123$ it has a very different purpose from that of the original. This intent to ridicule the style of the original distinguishes parody from substantially similar copies that have the same purpose as the original and function as market substitutes or replacements.

The first prong of the fair use test also considers the character of the use, specifically, whether the copy is commercial or educational in character. Generally speaking, commercial character will cut against a finding of fair use; copying for non-commercial purposes will not constitute infringement without a likelihood of economic harm. ${ }^{124}$ However, commercial character creates only a rebuttable presumption against fair use. The legislative history of section 107 makes clear that the "commercial or non-profit educational" language is

not intended to be interpreted as any sort of not-for-profit limitation on educational uses of copyrighted works. It is an express recognition that, as under the present law, the commercial or non-profit character of an activity, while not conclusive with respect to fair use, can and should be weighed along with other factors in fair use decisions. ${ }^{125}$

Indeed, the commercial/non-profit educational dichotomy offers neither a sufficient justification nor a reliable formula for a finding of infringement. ${ }^{126}$ Given the significance of the economic harm prong of the fair use test, the commercial character of the copying

123. Metro-Goldwyn-Mayer v. Showcase Atlanta Co-op. Prod., 479 F. Supp. 351, 357 (N.D. Ga. 1979) (quoting Dallas Cowboys Cheerleaders v. Pussycat Cinema, 467 F. Supp. 366, 376 (S.D.N.Y.), affd, 604 F.2d 200 (2d Cir. 1979)).

124. In Sony, the court found that, every commercial use of copyrighted material is presumptively an unfair exploitation of the monopoly privilege that belongs to the owner of the copyright .... A challenge to a non-commercial use of a copyrighted work requires . . . a showing by a preponderance of the evidence that [at least] some meaningful likelihood of future harm exists. If the intended use is for commercial gain, that likelihood may be presumed. But if it is for a non-commercial purpose, the likelihood must be deinonstrated.

Sony Corp. of Am. v. Universal City Studios, Inc., 464 U.S. 417, 451 (1984).

125. Id. at 449 n.32 (quoting H.R. REP. No. 1476, 94th Cong., 2d Sess., pt. 5., at 66 (1976), reprinted in 1976 U.S.C.C.A.N. 5659, 5680).

126. Compare Encyclopaedia Britannica Educ. Corp. v. Crooks, 447 F. Supp. 243 (W.D.N.Y. 1978) (infringement found where government corporation duplicated copyrighted materials for the poor) with Hustler Magazine, Inc. v. Moral Majority, Inc., 796 F.2d 1148 (9th Cir. 1986) (no infringement found where televangelist Jerry Falwell used copyrighted satirical cartoon from Hustler during televised fundraising campaign). 
should be considered no more than evidence of the copyist's intent to replace the original. ${ }^{127}$

2. Nature of the Copyrighted Work. The nature of the copyrighted work provides a counterpoint to the purpose and character of the unauthorized copy. The nature of the work implies its eligibility for copyright, that is, whether it is a "work of authorship" 128 that meets the requirements of originality and creativity. ${ }^{129}$ This element of fair use might best be understood as a depth test, with increasing protection available for more daring works.

Courts give wider latitude to the fair use of factual works than fictional ones. ${ }^{130}$ Since Feist, the factual content of works is generally ineligible for copyright because it lacks the requisite "creativity" of individual authorship; only where the arrangement or expression itself meets the criteria of originality and creativity will copyright protect such works. ${ }^{131}$ This "thinner" degree of copyright protection is conconant with a deliberate policy choice ${ }^{132}$ and an implicit recognition that factual works, like ideas, are more properly part of the public domain. ${ }^{133}$

127. See infra subsection IV(A)(4).

128. 17 U.S.C. \& 102(a) (1988 \& Supp. III 1991); see supra notes 41-42.

129. See infra note 131.

130. See, e.g., New Era Publications Int'l v. Carol Publishing Group, 904 F.2d 152, 157 (2d Cir.), cert. denied, 498 U.S. 921 (1990). The categories of "fact" and "fiction" are not fixed but represent a spectrum of fair use protection that varies according to the degree of originality and creativity involved. As one commentator has explained,

[E]ven within the field of fact works, there are gradations as to the relative proportion of fact and fancy. One may move from sparsely embellished maps and directories to elegantly written biography. The extent to which one must permit expressive language to be copied, in order to assure dissemination of the underlying facts, will thus vary from case to case and genre to genre.

Robert A. Gorman, Fact or Fancy? The Implications for Copyright, 29 J. COPYRIGHT Soc. 560,563 (1982).

131. Feist Publications, Inc. v. Rural Tel. Serv. Co., 111 S. Ct. 1282 (1991); see supra notes $59-60$.

132. "The law generally recognizes a greater need to disseminate factual works than works of fiction or fantasy." Harper \& Row, Publishers, Inc. v. Nation Enters., 471 U.S. 539, 563 (1985). As the Supreme Court stated in Sony,

[I] $t$ is not true that all copyrights are fungible. Some copyrights govern material with broad potential secondary markets. Such material may well have a broader claim to protection because of the greater potential for commercial harm. Copying a news broadcast may have a stronger claim to fair use than copying a motion picture. And, of course, not all uses are fungible.

Sony Corp. of Am. v. Universal City Studios, Inc., 464 U.S. 417, 455 n.40 (1984).

133. In rejecting a Lockean rationale for copyright, the Feist Court elided the distinc- 
3. Amount and Substantiality of Copying. The third prong of the fair use test measures "the amount and substantiality of the portion used in relation to the copyrighted work as a whole."134 This provision ensures that the copying exceeds a de minimis level in order to be actionable, ${ }^{135}$ and refers to both the amount copied from the original ${ }^{136}$ and the quality or value of that copied portion to the original ${ }^{137}$ and to the copy itself. ${ }^{138}$ Although

tion between the idea/expression dichotomy, supra notes $61-66$, and the fact/fiction dichotomy:

[C]opyright assures authors the right to their original expression, but encourages others to build freely upon the ideas and information conveyed by a work. This principle, known as the idea/expression or fact/expression dichotomy, applies to all works of authorship. As applied to a factual compilation, assuming the absence of original written expression, only the compiler's selection and arrangement may be protected; the raw facts may be copied at will.

Feist, 111 S. Ct. at 1290 (citations omitted).

However, the two sets of oppositions establish distinct elements of eligibility for copyright. Whereas an idea lacks the requisite "fixedness" of a "tangible medium of expression," 17 U.S.C. § 101 (1988); see supra note 41, a fact lacks the obvious individual creativity of fiction. Both ideas and facts are never severed from the commons but reside in the public domam outside copyright protection. See 1 NIMMER ON COPYRIGHT, supra note $13, \S \S 2.03[\mathrm{E}], 2.11[\mathrm{~A}]$.

Whether these dichotomies are analogous or even very useful is subject to debate. For some commentators, the whole notion of facts being "out there" in the world, to be discovered rather than created, has been problematic. Gordon, supra note 89, at $94 \mathrm{n.7}$ (citing Jane Ginsburg, Sabotaging and Reconstructing History: A Comment on the Scope of Copyright Protection in Works of History After Hoelling v. Universal City Studios, $29 \mathrm{~J}$. COPYRIGHT SOC'Y 647, 658 (1982); Wendy J. Gordon, On Owning Information: Intellectual Property and the Restitutionary Impulse, 78 VA. L. REV. 149, 154-56 nn. 21-22 (1992); Litman, supra note 7 , at $996-97)$.

134. 17 U.S.C. \& $107(3)$ (1988).

135. "As a rule, a taking is considered de minimis only if it is so meager and fragmentary that the average audience would not recognize the appropriation." Fisher v. Dees, 794 F.2d 432, 435 n.2 (9th Cir. 1986).

136. "It is certainly not necessary, to constitute an invasion of copyright, that the whole of a work should be copied, or even a large portion of it, in form or in substance." Folsom v. Marsh, 9 F. Cas. 342, 348 (C.C.D. Mass. 1841) (No. 4901).

137. "The taking is significant not only from a quantitative standpoint but from a qualitative one as well. The copied passages, if not the 'heart of the [original]' are at least an important ingredient of [it] as it now stands. To a large extent, they make the [original] worth reading." Salinger v. Random House, 811 F.2d 90, 98-99 (2d Cir.) (quoting Harper \& Row, Publishers, Inc. v. Nation Enters., 471 U.S. 539, 564-65 (1985) (quoting opinion of the district court, 557 F. Supp. 1067, 1072 (S.D.N.Y. 1983))), cert. denied, 484 U.S. 890 (1987).

138. The substantiality of the copying is determined in relation to the original as well as the copy. The Supreme Court has stated:

As the statutory language imdicates, a taking may not be excused merely because it is insubstantial with respect to the infringing work. As Judge Learned 
courts may find it difficult to answer these questions where something less than verbatim copying is involved, especially given the relative lack of caselaw on copyright infringement in the visual arts, substantiality is relevant in determining whether the copy functions as a replacement of the original under the fourth prong of the test. ${ }^{139}$

The permissible level of copying varies according to the purpose of the copy. Because parody must closely imitate the original, ${ }^{140}$ courts give it greater latitude than other kinds of fair use in determining substantiality. Under the common law "conjure up" test, a parodist may copy enough to evoke the original. ${ }^{141}$ Whether this measure is used as a ceiling ${ }^{142}$ or a floor, ${ }^{143}$ courts

Hand cogently remarked, "[N]o plagiarist can excuse the wrong by showing how much of his work he did not pirate." Conversely, the fact that a substantial portion of the infringing work was copied verbatim is evidence of the quahtative value of the copied material, both to the originator and to the plagiarist who seeks to profit from marketing someone else's copyrighted expression.

Harper \& Row, 471 U.S. at 565 (quoting Sheldon v. Metro-Goldwyn Pictures Corp., 81 F.2d 49, 56 (2d Cir.), cert. denied, 298 U.S. 669 (1936)).

139. "[A] substantial taking for parody purposes is permissible where, as here, the parody does not fulfill the demand for the copyrighted work." MCA, Inc. v. Wilson, 677 F.2d 180, 189 (2d Cir. 1981) (Mansfield, J., dissenting); see infra notes 150-53 and accompanying text.

140. See supra note 85 .

141. See Fisher v. Dees, 794 F.2d 432, 435 n.2 (9th Cir. 1986) ("A parody is successful only if the audience makes the connection between the original and its comic version. To 'conjure up' the original work in the audience's mind, the parodist must appropriate a substantial enough portion of it to evoke recognition."). Other cases that have used the test include: $M C A, 677$ F.2d at 184-85; Elsmere Music v. National Broadcasting Co., 623 F.2d 252, 253 n.1 (2d Cir. 1980); Walt Disney Prods. v. Air Pirates, 581 F.2d 751, 757-58 (9th Cir. 1978), cert. denied, 439 U.S. 1132 (1979); Berlin v. E.C. Publications, 329 F.2d 541, 545 (2d Cir.), cert. denied, 379 U.S. 822 (1964); Metro-Goldwyn-Mayer v. Showcase Atlanta Co-op. Prod., 479 F. Supp. 351, 359-60 (N.D. Ga. 1979); Columbia Pictures Corp. v. National Broadeasting Co., 137 F. Supp. 348, 354 (S.D. Cal. 1955).

142. See, e.g., Air Pirates, 581 F.2d at 757-58 (finding infringement where parody of Disney characters could have been achieved with less copying of the original).

143. The "conjure up" test is arguably a threshold for infringement; the copy must at least "conjure up" the original for an action to survive a motion to dismiss. As the Second Circuit has said:

[T] he concept of "conjuring up" an original came into the copyright law not as a limitation on how much of an original may be used, but as a recognition that a parody frequently needs to be more than a fleeting evocation of an original in order to make its humorous point. A parody is entitled at least to "conjure up" the original. Even more extensive use would still be fair use, provided the parody builds upon the original, using the original as a known element of modern culture and contributing something new for humorous effect or commentary.

Elsmere Music, 623 F.2d at 253 n.1 (citation omitted). 
should apply it in light of "the degree of public recognition of the original work."144 When the original is not immediately recognizable, more must be copied to invoke it for purposes of parody.

4. Economic Effect of the Copying on the Original. The fourth prong of the fair use test, the "effect of the use upon the potential market for or value of the copyrighted work," 145 is "the most important, and indeed, central fair use factor."146 Even at common law, fair use included a consideration of "the degree in which the use may prejudice the sale, or diminish the profits, or supersede the objects, of the original work."147 Since an owner need not show actual damages to prove copyright infringement, ${ }^{148}$ the first two common law measures-likelihood of harm to sales and profits-do not suffice as tests of economic harm. They are instead evidence of the central issue: Whether the copy "supersedes" or replaces the original. According to the U.S. Court of Appeals for the Ninth Circuit:

[T] he economic effect of a parody with which we are concerned is not its potential to destroy or diminish the market for the original-any bad review can have that effect-but rather whether it fulfills the demand for the original. Biting criticism suppresses demand; copyright infringement usurps it. Thus, infringement occurs when a parody supplants the original in markets the original is aimed at, or in which the original is, or has reasonable potential to become, commercially valuable. ${ }^{149}$

144. Fisher, 794 F.2d at 439 . It is the recognition of the work, not the author, that it relevant.

145. 17 U.S.C. \& 107(4) (1988).

146. Stewart v. Abend, 495 U.S. 207, 238 (1990) (quoting 3 NimMER ON COPYRIGHT, supra note 13, \& 13.05[A]); see also Harper \& Row, Publishers, Inc. v. Nation Enters., 471 U.S. 539, 566 (1985) (stating that effect on the market is the most important factor in determining fair use).

147. Folsom v. Marsh, 9 F. Cas. 342, 348 (C.C.D. Mass. 1841) (No. 4901).

148. As the Koons court explained, "[T] he owner of a copyright . . . need only demonstrate that if the unauthorized use becomes 'widespread' it would prejudice his potential market for his work." Rogers v. Koons, 960 F.2d 301, 312 (2d Cir.), cert. denied, 113 S. Ct. 365 (1992).

149. Fisher v. Dees, 794 F.2d 432, 438 (9th Cir. 1986) (citations omitted); see also Harper \& Row, 471 U.S. at 568 ("With certain special exceptions . . . a use that supplants any part of the normal market for a copyrighted work would ordinarily be considered an infringement.") (quoting S. REP. No. 473, 94th Cong., 1st Sess. 65 (1975)). 
Copyright thus protects the original (and its possible derivatives) against only that unfair competition ${ }^{150}$ from unauthorized copies that serve as market substitutes. ${ }^{151}$ Given that parody is a commentary on the original, only in those rare instances where the parody replaces the original is there "cognizable economic effect on the original," 152 that is, unfair competition amounting to infringement. The measure of whether the copy supersedes the original is actually an assessment of whether the parody has crossed some line in terms of substantiality. ${ }^{153} \mathrm{~A}$ work intended and interpreted as critical of the original could hardly be said to replace the original unless it copies so much of the original that one need not purchase the original in order to own it.

\section{B. Koons and the Fair Use Test}

Although the Koons court applied the statutory fair use factors, it failed to consider how those factors relate to parody as opposed to other kinds of fair use. This compounds the primary problem: The court's misinterpretation of copyright as complete protection against undifferentiated economic harm rather than as a limited form of protection against the harm posed by replacements. ${ }^{154}$

1. Purpose of the Use. It is fair to say that the defendants in Koons had mixed motives, that is, they wanted both to contrib-

150. Although the analogy to trademark law is plain, copyright is justified by the originality and creativity of the expression; trademark is justified by a desire to prevent consumer confusion. See supra notes $67-70$ and accompanying text.

151. This is a particularized economic harm that "close substitutes". in the market pose. A substitute is a "good which can be substituted for another good, or an input that can be substituted for another mput." THE MIT DICTIONARY OF MODERN ECONOMICS 406 (David W. Pearce ed., 3d ed. 1986) [hereinafter MIT DICTIONARY].

152. Fisher, 794 F.2d at 438 . The court stated that

[a]t the very least, where, as here, it is clear that the parody has neither the intent nor the effect of fulfilling the demand for the original, and where the parodist does not appropriate a greater amount of the original work than is necessary to "recall or conjure up" the object of his satire, a finding of infringement would be improper.

Berlin v. E.C. Publications, 329 F.2d 541, 545 (2d Cir.), cert. denied, 379 U.S. 822 (1964).

153. See supra subsection IV(A)(3); see also Wendy J. Gordon, Fair Use as Market Failure: A Structural and Economic Analysis of the Betamax Case and its Predecessors, 82 COLUM. L. REV. 1600, 1640 n.218 (1982) (discussing substantiality).

154. Rogers v. Koons, 960 F.2d 301, 312 (2d Cir.), cert. denied, 113 S. Ct. 365 (1992). See supra subsection IV(A)(4). 
ute to public edification and enjoyment and to make a handsome profit in the frenzied art market of the $1980 \mathrm{~s} .{ }^{155}$ As the court acknowledged, Koons is both a notorious self-promoter ${ }^{156}$ and an internationally recognized artist ${ }^{157}$ in the Pop Art tradition of Andy Warhol ${ }^{158}$ and the Dadaism of Marcel Duchamp. ${ }^{159}$ The commercialisin of modern culture is in large part the subject matter of these traditions, which parody cultural icons for satirical effect. Koons was in effect selling a sculpture that both parodied the original and satirized its commercialization as a mass-produced greeting card.

The Koons court's reliance on Sony Corporation of America v. Universal City Studios, Inc. ${ }^{160}$ for what it considered a sweeping presumption against commercial copying is misplaced, for Sony also addresses the issue of the commercial character of the copying in much more moderate language. ${ }^{161}$ The court's conclusion in Koons that the commercial character of String of Puppies is "[k]nowing exploitation of a copyrighted work for personal gain [and] militates against a finding of fair use"162 is highly problematic. The court equated the commercial character of the copy with bad faith on the part of Koons ${ }^{163}$ and asserted that by tearing

155. As the Koons court noted, "A New York Times critic complained that 'Koons is pushing the relationship between art and money so far that everyone involved comes out looking slightly absurd.' Koons, 960 F.2d at 304 (citing Michael Brenson, Greed Plus Glitz, with a Dollop of Innocence, N.Y. TIMES, Dec. 18, 1988, at B41).

156. The court called Koons a "controversial artist hailed by some as a 'modern Michelangelo,' while others find his art 'truly offensive.'" Id.

Koons, a Wall Street securities trader-turned-artist, has gained notoriety for such projects as Made in Heaven, an exhibition of photorealist nude paintings and sculptures of the artist with his wife Cicciolina (an Italian pornography star and member of parliament) in flagrante delicto. See Brooke Adains, Jeff Koons at Sonnabend, ART IN AM., Mar. 1992, at 117, 117-18.

157. The court noted that Koons had by the time of trial "approximately 100 Group Exhibitions and . . . eleven one-man shows" and was represented by Sonnabend in New York, as well as the Donald Young Gallery in Chicago and the Galerie Max Hetzler in Cologne, Germany. Koons, 960 F.2d at 304.

158. Id.

159. Id. at 309 .

160. 464 U.S. 417, 451 (1984) (stating "every commercial use of copyrighted material is presumptively an unfair exploitation of the monopoly privilege that belongs to the owner of the copyright"); see Koons, 960 F.2d at 309, 312.

161. "Copying for commercial gain has a much weaker claim to fair use than copying for personal enrichment." Sony, 464 U.S. at $455^{\prime}$ n. 40 .

162. Koons, 960 F.2d at 309.

163. The court construed the first prong of fair use as a question of "whether the 
off the Puppies photograph from the greeting card, Koons was trying to conceal the copyright from Demetz Studio. The assumption that profit-making intent is tantamount to bad faith is unfounded,${ }^{164}$ and it is difficult to imagine that hired Italian artisans would respond to an American copyright mark. ${ }^{165}$ The court's focus on the copyright mark was symptomatic of its foregone conclusion that Koons was guilty of "piracy,"166 "plagiarism,"167 and "wilful and egregious behavior." 168

Moreover, if the aim of copyright is to guard against unfair competition, restricting the fair use defense on the basis of the copyist's intent is not particularly useful. ${ }^{169}$ The categories of "commercial" and "non-profit educational" use are neither discrete nor predictive of economic harm. Non-profit educational copying could conceivably work greater harm in the market for the original than copying done for commercial reasons. Consider, for example, two situations: in one, a professor makes copies of an entire textbook for his students but makes no profit; in the second, he creates a companion study guide for the textbook for profit. In the former situation, there is a clear case of replacement; in the latter, the unauthorized derivative work may even enhance the market for the textbook. Just as the non-profit educational character of the copying should not insulate it against a finding of infringement, neither should the commercial use of the copy automatically defeat a defense of fair use.

2. Nature of the Copyrighted Work. In Koons, the court found the original photograph to have "more in common with fiction than with works based on facts, such as, for example, biographies $^{170}$ or telephone directories." ${ }^{\text {171 }}$ The court did not elabo-

original was copied in good faith to benefit the public or primarily for the commercial interests of the infringer." Id. (emphasis added). The court concluded that Koons had acted in "bad faith." Id. at 310.

164. See supra subsection $\operatorname{IV(A)(1).~}$

165. The court found that Koons had acted in bad faith based on Koons's commercial intentions (i.e., the "[k]nowing exploitation of a copyrighted work for personal gain") and his failure to acknowledge his removal of the back of the Puppies greeting card where the copyright mark appeared (i.e., the "wrongful denial of exploitative conduct towards the work of another"). Koons, 960 F.2d at 309.

166. Id. at 303,311 .

167. Id. at 303 .

168. Id. at 313 .

169. See supra subsection $\operatorname{IV(A)(4).~}$

170. The court may have been referring to Harper \& Row, Publishers, Inc. v. Nation 
rate on this conclusion, suggesting only that the nature of the original might be analyzed in terms of whether it is "creative, imaginative, or represents an investment of time in anticipation of a financial return."172 As these factors could be applied just as readily to non-fiction, the finding that Puppies merits the "thicker" degree of copyright protection appropriate to fictional works limits the fair use of the photograph without sufficient justification.

3. Amount and Substantiality of Copying. The Koons court acknowledged that parody is entitled to copy the original more liberally ${ }^{173}$ but found that Koons had exceeded a "permissible level of copying under the fair use doctrine" by copying nearly the entire photograph. ${ }^{174}$ By focusing on the common subjects of the photograph and sculpture, however, the court ignored the differences in their copyrightable expressions. ${ }^{175}$ Although Koons obviously copied the pose and the portraiture of the Scanlons and their dogs, these elements did not comprise the whole of the photograph. The lighting, tonality, and contrast of Puppies are arguably the essential elements of the work and support its eligibility for copyright. Although it is difficult to quantify such attributes, it is significant that Koons copied none of these elements in the polychromed wooden sculpture.

Furthermore, the court's analysis is contradictory; having found the sculpture satirical but insufficient as a parody of the Rogers photograph, ${ }^{176}$ the court nevertheless concluded that Koons could have parodied the photograph by copying less than

Enters., 471 U:S. 539 (1985) (finding infringement where magazine used verbatim quotes of forthcoming memoir by President Ford) or perhaps to Folsom v. Marsh, 9 F. Cas. 342, 348 (C.C.D. Mass. 1841) (No. 4901) (finding infringement where biographer of George Washington used materials from another biography).

171. The court refers to Feist Publications, Inc. v. Rural Tel. Serv. Co., $111 \mathrm{~S}$. Ct. 1282 (1992) (finding white pages of telephone directory to be ineligible for copyright because they lack requisite element of creativity).

172. Koons, 960 F.2d at 310 (citing MCA, Inc. v. Wilson, 677 F.2d 180, 182 (2d Cir. 1981)).

173. "We have consistently held that a parody entitles its creator under the fair use doctrine to more extensive use of the copied work than is ordinarily allowed under the substantial similarity test." Id.; see Elsmere Music, Inc. v. National Broadcasting Co., 623 F.2d 252, 253 n.1 (2d Cir. 1980).

174. Koons, 960 F.2d at 311.

175. See supra notes $65-66$ and accompanying text.

176. "[I]t is difficult to discern any parody of the photograph 'Puppies' itself." Koons, 960 F.2d at 310. 
he did. ${ }^{17}$ It must be noted, however, that although the style of a famous artist might be "conjured up" with relatively minimal copying of the original, a much higher level of copying undoubtedly is required to parody a popular commercial greeting card by a largely unknown photographer. To copy less would be to cast doubt on the parody defense and to fall prey to the very charge of "piracy" that the court levelled at Koons. ${ }^{178}$

4. Economic Effect of the Copying on the Original. The analysis of whether String of Puppies is a replacement of Puppies and thus competes unfairly in the market for the photograph should have been simple, yet the court erred in analyzing this prong of the fair use test. The court's interpretation of copyright as a prophylactic against the possibility of undifferentiated "economic harm" ignored the limitations of the owner's statutory rights. The court failed to consider the formal differences in the works and in their respective contexts of consumption. To purchase String of Puppies is not to own the equivalent of a fine art reproduction of the photograph. The sculpture is not just a relatively faithful copy of Puppies, but a comment on the photograph as an object of humor and contempt-a burlesque of the proud couple with their puppies. Moreover, the inclusion of the sculpture in the "Banality Show" plainly evinces Koons's intent to respond to the way in which Rogers has commercialized the sentimental piece in a licensed greeting card. ${ }^{179}$

Rogers's copyright in the photograph does not entitle him to control all reproductions of Puppies ${ }^{180}$ but only those that properly qualify as derivative works. Because String of Puppies comments on the greeting card of Puppies, it stands in a wholly different relation to the photograph. Unlike the greeting card, String of Puppies does not merely expand the market for the photograph; as speech, it operates outside the right to derivative works.

177. The photograph was copied "much more than would have been necessary even if the sculpture had been a parody of plaintiffs work." Id. at 311.

178. Id.

179. See supra notes $110-11$ and accompanying text.

180. See Sony Corp. of Am. v. Universal City Studios, Inc., 464 U.S. 417, 432-33 (1984); see also supra note 74. 
Thus, the court's concern that Koons had "exploited" Puppies without paying the "price" of a license fee was misplaced. ${ }^{181}$ In light of Koons's treatment of the photograph, it is extremely unlikely that Rogers would be willing to grant a license to Koons, ${ }^{182}$ an assumption that supports a finding of parody in String of Puppies. Rather than competing with Puppies in the market for derivative works, the sculpture serves the very different purpose of criticism. Insofar as copyright can be analyzed in terms of markets, ${ }^{183}$ this is a case of "market failure"184 and qualifies as fair use on economic, as well as legal, grounds. ${ }^{185}$

If String of Puppies does indeed pose a threat to Puppies or its derivative works, ${ }^{186}$ it is because of its scornful critique rather than its attempt at "passing off" as the original. The court erred

181. Koons, 960 F.2d at 312.

182. Being "reluctant to license" copies that criticize their works, copyright owners have "anti-dissemination motives" with regard to parody. Gordon, supra note 154 , at 1632-33; see also Fisher v. Dees, 794 F.2d 432, 437 (9th Cir. 1986) ("Parodists will seldom get permission from those whose works are parodied. Self-esteem is seldom strong enough to permit the granting of permission even in exchange for a reasonable fee . . . . The parody defense to copyright infringement exists precisely to make possible a use that generally cannot be bought.") (citations omitted).

183. See generally Gordon, supra note 153 , at $1605-15$ (providing an overview of the market model and arguing for its applicability to the copyright context). Although fair use requires no economic rationale, see infra notes 209-15, a market-based analysis supports the legal arguments for parody as fair use in that it shows that if parody has no price, there may be no market for parody.

184. "Market failure" is "[t]he inability of a system of private markets to provide certain goods, either at all or at the most desirable or 'optimal' levels." MIT DicTiONARY, supra note 151, at 264.

Under the "market failure" theory,

[a]n economic justification for depriving a copyright owner of his market entitlement exists only when the possibility of consensual bargain has broken down in some way. Only where the desired transfer of resource use is unlikely to take place spontaneously, or where special circumstances such as market flaws impair the market's ordinary ability to serve as a measure of how resources should be allocated, is there an economic need for allowing nonconsensual transfer. Thus, one of the necessary preconditions for premising fair use on economic grounds is that market failure must be present.

Gordon, supra note 153, at 1615 .

185. "Because the owner's antidissemination motives make licensing unavailable in the consensual market, and because the free flow of information is at stake, a strong case for fair use can be advanced in these cases." Gordon, supra note 153, at 1633.

186. As the Koons court noted, "[i]t is obviously not implausible" that String of Puppies has "reduced" the market for licensed sculptural versions of Puppies, just as photographs of String of Puppies "would prejudice Rogers's potential market for the sale of the Puppies notecards." Rogers v. Koons, 960 F.2d 301, 312 (2d Cir.), cert. denied, 113 S. Ct. 365 (1992). 
in its assumption that copyright guards against any use that "undercuts demand" for the original or derivative works. ${ }^{187}$ This undifferentiated notion of economic harm is an overly broad interpretation of that prong of the fair use test and compounds the court's error in treating the commercial character of the copy as infringement per $\mathrm{se}^{188}$ without further analysis of evidence to the contrary.

The court's conclusion that undercutting the demand for the original "chills creation of such works" was neither an "inevitable consequence" of unfair copying nor an adequate rationale for copyright. ${ }^{189}$ One the one hand, it is not difficult to imagine unauthorized copying which spurs demand for the original but is nevertheless unfair under the replacement test. On the other hand, the Copyright Act, through its explicit protection of fair use, encourages at least some unauthorized copying. As the Second Circuit has said, "The 'parody' branch of the 'fair use' doctrine is itself a means of fostering the creativity protected by the copyright law. It also balances the public interest in the free flow of ideas with the copyright holder's [property] interest in the exclusive use of his work." 190

The rationale for copyright is not just to encourage the production of expressive works but "to generate incentives for the production of works that satisfy consumer tastes."191 To the extent that parody criticizes the original and "reveals [its] flaws," it is speech and contributes useful information to the public domain. If consumers find the criticism compelling, "it is appropriate that demand for the work should decrease." 192 Copyright does not protect against any undercutting of demand by an unauthorized copy but only against a decrease caused by the replacement or "substitution" of the original. As one commentator has said,

187. Id.; $c f$. Fisher v. Dees, 794 F.2d 432, 438 (9th Cir. 1986) (finding that the only cognizable economic harm from parody is that which "supplants" the original); see supra note 149 and accompanying text.

188. Koons, 960 F.2d at 312; see supra notes $160-65$ and accompanying text.

189. Koons, 960 F.2d at 312.

190. Warner Bros., Inc. v. American Broadcasting Cos., 720 F.2d 231, 242 (2d Cir. 1983).

191. Gordon, supra note 153 , at 1633 .

192. Id. 
"when decreased demand arises out of changed consumer preferences, that should be reflected in decreased revenues."193

\section{TOWARD AN EXPansive Theory of FaIR USE}

Koons is significant as a selective interpretation of the Supreme Court's dicta on fair use in Sony Corporation of America $v$. Universal City Studios, Inc. ${ }^{194}$ an interpretation which departs from the historical protection of parody ${ }^{195}$ and reduces the fair use test to a question of the parodist's commercial motives. As a result, the Koons analysis sharply narrows the fair use exception for parody. This near elimination of a statutory fair use defense contravenes the legislative intent behind the Copyright Act and compromises the First Amendment rights preserved therein.

Exclusive rights in speech give the copyright holder the legal power to enjoin others from speaking, ${ }^{196}$ in contravention to the privileged place of speech in constitutional law ${ }^{197}$ and political practice. ${ }^{198}$ Furthermore, the question of who owns speech, determined against the shifting ground of "originality,"199 creates problems of proof and contradictory notions of exclusivity. ${ }^{200}$ Fi-

193. Id. at 1633 n.183.

194. 464 U.S. 417 (1984); see supra notes $160-65$ and accompanying text.

195. See supra notes 173-74. As the Second Circuit has stated, as a general proposition, we believe that parody and satire are deserving of substantial freedom-both as entertainment and as a form of social and literary criticism. As the readers of Cervantes' Don Quixote and Swift's Gulliver's Trav$e l s$, or the parodies of a modern master such as Max Beerbohm well know, many a true word is indeed spoken in jest.

Berlin v. E.C. Publications, Inc., 329 F.2d 541, 545 (2d Cir.), cert. denied, 379 U.S. 822 (1964).

196. Civil infringement of copyright has been described as "actionable on a strict liability basis." Litman, supra note 7, at 971; see Gordon, supra note 153, at 1390-91. Statutory remedies include damages and additional profits of the infringer, 17 U.S.C. $\S 504$ (1988), the possibility of costs and attorney's fees, id. § 505, and impounding and disposing of the infringing copies, $i d$. $\S 506(\mathrm{~b})$.

197. "Congress shall make no law ... abridging the freedom of speech . ..." U.S. CoNST. amend. I.

198. "The fact remains that authorizing speech, historically, has been the work of the state ... [a]nd it is for reasons implicit in that larger history that intellectual property and authorship cannot easily be defended in any society today which prizes freedom of expression." Lange, supra note 106 , at 144.

199. See supra notes $68-70$ and accompanying text.

200. Independently created works that are, to the observer, identical are nevertheless independently copyrightable. This contradiction can be understood only if intellectual property is seen as a means of enjoining a particular behavior-use of copies-rather than as a means of protecting some unique property. As Judge Learned Hand explained, 
nally, even if speech is justifiably "original" and exclusive use of it is uncontested, the resistance to complete privatization of intellectual property stems from a foundational notion that speech is not so much property but social practice. ${ }^{201}$

Even to the extent copyright commodifies speech, ${ }^{202}$ it refuses to recognize the elements of production as wholly private goods. Copyright is thus a regime of incomplete ownership which reflects the quasi-property status of expressive works and the primacy of the public domain. ${ }^{203}$ The mythology of artistic creation aside ${ }^{204}$ writings are produced not from the purely private imaginings of the author but, to some extent, with materials-signs, images, the formalistic systems of language-from the public domain. In their transformation into intellectual property, these materials are never quite removed from the commons but

Borrowed the work must indeed not be, for a plagiarist is not himself pro tanto an "author"; but if by some magic a man who had never known it were to compose anew Keats's Ode on a Grecian Urn, he would be an "author," and, if he copyrighted it, others might not copy that poem, though they might of course copy Keats's.

Sheldon v. Metro-Goldwyn Pictures Corp., 81 F.2d 49, 54 (2d Cir.), cert. denied, 298 U.S. 669 (1936).

201. Language can be viewed as a reaction to human behavior:

"If we want to understand any concept we must obtain a view of the human behaviour, the activities, the natural expressions, that surround the words for that concept." The relation between discourse and forms of life is necessary, not contingent; for Wittgenstein the language of sensation in particular would be incomprehensible if it were not closely bound up with actual behaviour.

Terry Eagleton, Wittgenstein's Friends, in AGAINST THE GRAIN 106 (1986) (footnote omitted) (quoting Norman Malcolm, Wittgenstein's Philosophical Investigations, reprinted in Wittgenstein: The Philosophical InVestigations 91-92 (George Pitcher ed., 1968)).

202. The classic critique of private property is the Marxist theory of commodity fetishism:

The commodity is the form products take when [the social] production [of material conditions of existence] is organized through exchange.... The commodity form of production simultaneously makes private labour social as products are exchanged, and fragments social labour into private labour. This confusion of relations between people with relations to things is the fundamental contradiction of commodity production. Marx calls it the fetishism of commodities, ... the process by which the products of human labour come to appear as an independent and uncontrolled reality apart from other people who have created them. The historical mission of socialism, in Marx's view, is to transcend not just the contradictions of capitalist production, but the contradictions of the commodity form on which capitalist production rests.

A Dictionary of MarXist Thought 86-87 (Tom Bottomore et al. eds., 1983).

203. See supra note 7 and accompanying text.

204. "According to the romantic model [of authorship], creative processes are magical and are, therefore, likely to produce unique expression." Litman, supra note 7, at 1008. 
become at best quasi-public or "mixed" goods, ${ }^{205}$ if only because signification makes no sense outside some social context. ${ }^{206}$

Rather than a conventional system of private property ownership, copyright is more properly understood as a system of gatekeeping, a regime for controlling how and when creative works are ceded-and elements of production returned-to the public domain. An analysis of copyright begins not with the rights of the autinor or owner against others, but more properly with public rights to creative works even as they are protected under copyright. Fair use is the repository of public rights in works that are. still under their statutory term of copyright protection. The rationale is not so much a forced sharing of works otherwise exclusively created and owned as an insistent reminder that creative works do not arrive sui generis from the depths of the author's imagination, but are always already imbedded in the social conditions of production and consumption. Authorship of "original" works is a legal fiction, albeit a necessary one. ${ }^{207}$ Ownership is the site of alienable property exchange; fair use is its limit.

Fair use is predicated upon a qualified right to use copyrighted works: The right to speak about them but not to duplicate or replace them with functional substitutes during the term of copyright. Fair use is distinguishable from copying generally because its products do not presume to replace the original so much as to call attention to its existence and comment on it. ${ }^{208}$ To allow fair use

205. See infra note 210.

206. Insofar as it is signification, "a system of signs, speech requires the identity of a speaking subject in a social institution which the subject recognises as the support of its identity." Julia Kristeva, Signifying Practice and Mode of Production, 1 EDINBURGH '76 Magazine, at 1, quoted in Dick Hebdige, Subculture: The Meaning of STYLe 165 n.6 (Terence Hawkes ed., 1979).

207. "[T] $]$ he requirements of human existence will not suffer the author to die. What does it matter who is speaking? The answer is--when it is we who are speaking with those with whom we speak-everything." Lange, supra note 106, at 149-50. Lange explains that apart from the Foucauldian notion of authorship as "an artifact of authority," there is "authorship in the preliminary sense of identifying, merely entre nous, the 'person to whom something owes its origin."' Id. at 148. He argues that this notion is not only defensible, but inevitable as well .... [I]t has been an essential requirement of human existence froin our earliest beginnings.

Authorship in this original sense situates us in our relationship with others, and is therefore the means by which we gauge our place in the world; it is Id.

a necessary antecedent to understanding.

208. All of the statutory examples of fair use-criticism, comment, news reporting, teaching, scholarship, and research-are characterized to some degree by their speech on 
is to ensure that copyright does not encroach unduly on the permissible subject matter of speech.

A purely economic rationale $e^{209}$ is not a justification for copyright; the premise of scarcity is inapt given the relatively unlimited nature of the goods, their quasi-public status, ${ }^{210}$ and their distinction from derivative works. ${ }^{211}$ Moreover, fairness of use is not a function of the productive character ${ }^{212}$ of expressive works but of the privileged place of speech in constitutional law. ${ }^{213}$ The issue is maintaining enough public access to protected materials in order to preserve the right to speak about them, regardless of whether it is efficient to do so. ${ }^{214}$ The doctrine of fair use guarantees that copyright protection against a kind of unfair competition will not compromise public First Amendment rights. ${ }^{215}$

There remains the problem of what constitutes fair use in a given situation. The application of the doctrine has proved to be difficult in practice. When the definition of "Writings" of "Authors"216 is expansive enough to include conduct protected as

copyrighted works. See 17 U.S.C. $\S 107$ (1988 \& Supp. III 1991).

209. According to Judge Richard Posner:

A use is fair ... when the costs of transacting with the copyright owner over permission to use the copyrighted work would exceed the benefits of transacting. These benefits include not only ... economizing on other transactions but also, and more important, stimulating the production of intellectual property by enabling its creators to appropriate as private gain the social value of their creation.

Richard A. Posner, When Is Parody Fair Use?, 21 J. LEGAL STUD. 67, 68 (1992).

210. Copyright sustains the status of intellectual property as mixed goods, at once affording some rights of exclusion to owners but denying them the ability to withdraw their properties from the public domain entirely.

211. See supra notes $48-54$ and accompanying text.

212. As the Sony court explained,

[t]he distinction between "productive" and "unproductive" uses may be helpful in calibrating the balance [between copyright and fair use], but it cannot be wholly determinative. Although copying to promote a scholarly endeavor certainly has a stronger claim to fair use than copying [a television program] to avoid interrupting a poker game, the question is not simply two-dimensional .... The statutory language does not identify any dichotomy between productive and nonproductive time-shifting, but does require consideration of the economic consequences of copying.

Sony Corp. of Am. v. Universal City Studios, Inc., 464 U.S. 417, 455-56 n.40 (1984).

213. See supra notes 8-12 and accompanying text.

214. See supra note 76 and accompanying text.

215. See supra subsection $\operatorname{IV}(A)(4)$.

216. U.S. CONST. art. I, § 8, cl. 8; see supra note 6 . The term "Writings" is broadly defined "to include any physical rendering of the fruits of creative intellectual or aesthetic labor." Goldstein v. California, 412 U.S. 546, 561 (1973). 
"speech," courts may find it difficult to ascertain the degree to which a copyright owner may enjoin or otherwise penalize the speech of a non-owner in the name of copyright protection.

The problem is especially acute in the case of fair use criticism or comment, ${ }^{217}$ of which parody is a particular genre. ${ }^{218}$ Not only does the copyright owner have an economic incentive to suppress any criticism which might devalue the work, as an author he may have a moral investment in the work which suffers from derogatory comment. Although the Copyright Act is designed to serve social welfare aims rather than individual "moral rights,"219

217. 17 U.S.C. \& 107 (1988 \& Supp. III 1991); see supra text accompanying note 124.

218. See supra note 190 and accompanying text.

219. The legislative history on this point is unequivocal:

The enactment of copyright legislation by Congress under the terms of the Constitution is not based upon any natural right that the author has in his writings, ... but upon the ground that the welfare of the public will be served and the progress of science and useful arts will be promoted by securing to authors for limited periods the exclusive rights to their writings.

H.R. REP. No. 2222, 60th Cong., 2d Sess. 7 (1909) (emphasis added).

However, with U.S. participation in the Berne Convention for the Protection of Literary and Artistic Property, Sept. 9, 1886, 828 U.N.T.S. 221 (Paris revision, July 24, 1971) [hereinafter Berne Convention], American copyright law has been amended to permit limited protection of the author's "moral rights." As the treaty was not self-executing, David Nimmer, Nation, Duration, Violation, Harmonization: An International Copyright Proposal for the United States, 55 LAw \& CoNTEMP. ProBs., Spring 1992, at 211, 223 n.84, Congress passed the Berne Convention Implementation Act of 1988, Pub. L. No. 100-568, 102 Stat. 2853 (1988), in order to harmonize American copyright law with international law.

Congress anended the Copyright Act again with the Visual Artists Rights Act of 1990, Pub. L. No. 101-650, 104 Stat. 5128 (1990) (codified at scattered sections of 17 U.S.C. (Supp. III 1991)). The Visual Artists Rights Act in effect grafted the moral rights section (i.e., Article 6bis(1)) of the Berne Convention onto the Copyright Act as 17 U.S.C. § 106A (Supp. III 1991), the "Rights of Attribution and Integrity" of creators (not owners) of visual art. Section 106A provides that for the lifetime of the artist, he

(1) shall have the right-

(A) to claim authorship of that work, and

(B) to prevent the use of his or her name as the author of any work of visual art which he or she did not create;

(2) shall have the right to prevent the use of his or her name as the author of the work of visual art in the event of a distortion, mutilation, or other modification of the work which would be prejudicial to his or her honor or reputation ....

Id. § $106 \mathrm{~A}(\mathrm{a})$.

To these rights protecting against "passing off" or "reverse passing off" are added the rights protecting against the intentional distortion, mutilation, or modification that would be prejudicial to the honor or reputation of the artist. Id. $\$ 106 \mathrm{~A}(\mathrm{a})(3)(\mathrm{A})$. However, the wording of $\$ 106 \mathrm{~A}$ does not include protection against "other derogatory action" as mentioned in Article 6bis of the Berne Convention, supra, a significant omission 
the author may be more motivated to bring an infringement action on the theory that even speaking about the work in published form should be a prohibited copying or use of the original.

Copyright law must respond to authors' concerns while both protecting public speech and encouraging the production of intellectual property and its deposit into the public domain. The management of these multiple policy objectives demands a theory of fair use that distinguishes a copy that serves to replace a protected work from one that simply speaks about it. In the case of parody, the failure to apply a replacement test threatens to extinguish a potent form of rebuttal.

\section{CONCLUSION}

In Koons, the court substantially narrowed the parody defense and departed from its precedent of protecting the fair use privilege of comment and criticism. The result is inconsistent with copyright jurisprudence and contrary to both congressional intent ${ }^{220}$ and the goals of copyright law to "stimulate artistic creativity for the general public good"221 and preserve First Amendment rights to free speech and the press. Although parody is "not . . presumptively fair use," it is well established that "[c]opyright is not designed to stifle critics."222

The court's assumption that copyright guards against an undifferentiated notion of. "economic harm" ignored the relationship of parody to the original and the protection of parody as fair use. In interpreting Sony as a per se rule against commercial copying, the Koons court presumed the likelihood of economic harm without

given the status of parody as fair use under American copyright law.

Whether the Copyright Act can in fact be reconciled with European moral rights is undecided. In any case, neither the moral rights of authors under $\S 106 \mathrm{~A}$ nor the economic rights of authors and owners under 17 U.S.C. § 106 (1988) derogates from the doctrine of fair use codified by 17 U.S.C. $\$ 107$ (1988 \& Supp. III 1991). The statutory language is unequivocal: "Notwithstanding the provisions of $\S \S 106$ and $106 \mathrm{~A}$, the fair use of a copyrighted work . . . is not an infringement of copyright." 17 U.S.C. $\S 107$ (Supp. III 1991).

220. See supra note 114; see also Harper \& Row, Publishers, Inc. v. Nation Enters., 471 U.S. 539, 549 (1985).

221. Sony Corp. of Am. v. Universal City Studios, Inc., 464 U.S. 417, 432 (1984).

222. New Line Cinema Corp. v. Bertlesman Music Group, 693 F. Supp. 1517, 1525 (S.D.N.Y. 1988) (quoting Fisher v. Dees, 794 F.2d 432, 435 (9th Cir. 1986)) (finding that song parody was fair use). 
analyzing whether the statutory test of fair use supports such a finding. The role of copyright law is better understood as that of a gatekeeper, controlling access to copyrighted works but guaranteeing, via fair use, some measure of availability to the public. In fact, public access was at the heart of the decision in Sony. ${ }^{223}$

To construe fair use as a replacement test returns copyright to its proper focus: The primacy of the public domain and a balancing of public and private rights given the social nature of speech. Just as the dichotomies of idea/expression and fact/fiction serve as markers of what kind of speech may be treated as property, the replacement test draws a line between fair use and infringement. As Wendy Gordon has explained, "[W] work exists is an essential prerequisite for the second author's point to be made, then the special policies in favor of allowing free use of facts should come into play."224 This is an argument for the expansive test of fair use permitted for factual works as opposed to fictional ones.

It should not be difficult to distinguish an attempt to replicate a copyrighted work from an effort to humorously criticize it. The real issue is whether that criticism or comment also manages to replace the original. In the case of parody, there is little threat of chilling the production of original works: What author anticipates ridicule at the hands of another, or would even be deterred by the possibility of such criticism? Parody is a protected form of speech and an independent source of creative production. In order to preserve a place for parody as fair use, it is imperative to consider the status of the copy in relation to the original rather than to assume that commercial purpose poses a threat of cognizable economic harm. The issue is not just possible economic harm but the kind of unfair competition by parody that fails to distinguish itself as such or otherwise serves as a functional equivalent to the original. Absent a finding that the parody is indeed a replacement, it should enjoy statutory protection as a fair use.

\footnotetext{
223. The Court cited the opinion of the district court that "public interest in increasing access to television programming [is] an interest that 'is consistent with the First Amendinent policy of providing the fullest possible access to information through the public airwaves." "Sony, 464 U.S. at 425 (quoting opinion of the district court, 480 F. Supp. 429, 454 (C.D. Cal. 1979).
}

224. Gordon, supra note 89 , at 97. 